\title{
Local Government Policy in BPHTB Tax Picking Up On the Transaction Sale and Purchase of Land And / Or Building
}

\begin{abstract}
Catur Agung Bintoro ${ }^{1}$ and Amin Purnawan ${ }^{2}$
Abstract. The purpose of this study were 1) For the Local Government Policy in BPHTB Tax Picking Up On the Transaction Sale and Purchase of Land and / or Building 2) To know Constraints faced by the Notary and PPAT in Tax levy BPHTB Purchase Transactions Over Land And / Or Building method used is empirical juridical approach in order to obtain adequate results. Specifications research used in this study is a descriptive analysis, from this study is expected to obtain a detailed and systematic description of the problem to be studied. Based on data analysis concluded that: 1) The policy conducted by the Central Government is to give broad authority to manage their own household, including the authority to explore potential financial income areas one of which is the local tax. BPHTB tax requires that the buying and selling prices reported are approaching the fair market value of that property. It is sometimes difficult to implement given the magnitude of the price of the transaction will affect the costs associated with the transaction. 2) Some of the obstacles faced by the Notary and PPAT The BPHTB levying taxes as dishonest taxpayers to include the value of the transaction, the clerk is still difficult and takes a long time in the field verification process, lack of transparency in the market price of land, lack of good ithikad the seller, as well as the lack of public knowledge about this BPHTB tax.

Keywords: Policies; Local Government; Tax; BPHTB; Transactions.
\end{abstract}

\section{Introduction}

State of Indonesia in its development has resulted in a very rapid development in national life that needs to be continued with the support of government and the full potential of the society, therefore the state put the tax as one embodiment of state obligations is a means of participation in financing the state and national development. ${ }^{3}$

The regional administration can not be separated from their application and use of budgets and local revenue. Every year local authorities will make the local budget (hereinafter referred to as the budget) will be used as the implementation of regional development. In the budget revenues are one of the local revenue that can be obtained from local taxes and levies. According PJA Andriani, the tax is a contribution to the state that can be imposed, which shall be payable by the payment to them under the rules by not getting back achievement, which directly can be appointed, and that the use to finance public pengeluaranpengeluaran related tasks needed to govern the area. ${ }^{4}$

Aside from being a source of funds for financing the state and national development that takes place continuously and sustainably, the tax is also used as a source of

\footnotetext{
${ }^{1}$ Master of Notary UNISSULA, Semarang, Email : caturagung78@gmail.com

2 Lecturer Master of Notary UNISSULA, Semarang

3 The preamble of Act Number 21 of 1997 on Customs Acquisition of Land and Buildings.

${ }^{4}$ R. Santoso Brotodiharjo, 1987, Pengantar IImu Hukum Pajak, Edition-3, PT.Eresco, Bandung, p.2
} 
monetary and investment policies that have an impact on economic growth so that the welfare of the Indonesian people, the better. ${ }^{5}$

Taxes are the contributions of the people in the state treasury under the Act (which can be imposed) by not got the services of lead (contra) directly demonstrated and used to pay for general expenses that benefit the wider community. ${ }^{6}$ The provisions concerning the taxation provided for in Article 23 letter A of the Constitution of 1945, which says that taxes and other charges for the purposes of coercive state governed by the Act. Article 23 letter A of the Constitution of 1945 as one of the legal basis for the establishment of Law General Provisions and Tax Procedures (Act CTP), containing the principle of legality which lays the authority to levy any tax on the state on condition must be based on the provisions of the Act. It is intended that the state would not act arbitrarily when picked up most of the wealth of the people, even if it is used for the benefit of the people.

Transfer of Tax on Acquisition of Land and Building (BPHTB) of the tax into local tax center, a strategic step in the implementation of fiscal decentralization in Indonesia. BPHTB redirection policy is marked by the enactment of Act No. 28 of 2009 on Taxes and Levies on September 15, 2009. The transition period diversion of local tax BPHTB be held for 1 (one) year from the enactment of Act No. 28 of 2009 effective local taxes in effect be no later than on January 1, 2011, but for areas that are already ready for collection BPHTB prior to 1 January 2011 allowed under the provisions have no legal basis to collect BPHTB.

During the transfer process of the Central Government ordered to each regency / city to prepare everything related to facilities and infrastructure, and policies that support the implementation of the transfer policy BPHTB. BPHTB transfer policy as a local tax based on the premise that BPHTB considered to meet the criteria for a good local taxes, to increase revenue (PAD), increase accountability regional (local accountability), and based on international practice (good practice internationally). ${ }^{7}$

Readiness of the region to conduct BPHTB levy on taxpayers should be based on local policy issued local regulations (Perda) on BPHTB, because the policy is the basis for local governments to levy any BPHTB to taxpayers registered in the region. For those areas that do not have regulations on the BPHTB then not allowed to charge any fees BPHTB.

Based on the background of the problems that have been raised the problem in this research is formulated as follows: How Local Government Policy BPHTB Tax Picking Up Transaction on the Sale and Purchase of Land and / or Building?; What are the constraints faced by the Notary and PPAT in levy of BPHTB Tax on the Purchase Transactions Over Land And / Or Building ?

\section{Research methods}

Method approach used in this thesis is empirical juridical approach or juridical sociology. ${ }^{8}$ Specifications of this research is descriptive. Types and sources of data in

\footnotetext{
${ }^{5}$ Setu Setyawan and Eny Suprapti, 2006, Perpajakan, Bayumedia Publishing dan UUM Press, Malang, p. 1

${ }^{6}$ Rochmat Soemitro in Mardiasmo, 2011, Perpajakan, Revision Edision, Penerbit Andi Offset, Yogyakarta p. 1

7 Ministry of Finance of the Republic of Indonesia, the Review of Implementation of Transfer of Tax on Acquisition of Land and Building (BPHTB) into Local Tax, (Jakarta: Directorate General of Fiscal Balance, 2011), p. 2-3.

8 J.Supranto, 2003, Metode Penelitian Hukum Dan Statistic, PT.Rineka Cipta, Jakarta, p. 2
} 
Volume 6 Issue 2, June 2019

this study was obtained through primary data and secondary data. In this study, data collection tools used is the study of documents or library materials, and interviews or interviews. Data analysis methods used to solve the problem is by using qualitative analysis method that analyzes by describing the data field findings from interviews and documentary studies

\section{Discussion}

\subsection{Local Government Policy In the BPHTB Tax Picking Up Transaction on the Sale and Purchase of Land and / or Buildings}

According to Act No. 28 of 2009 on Regional Taxes and Levies, Local Tax is a mandatory contribution by persons or bodies to areas without immediate rewards are balanced, can be imposed by applicable laws and regulations used for governance and local development.

Biggest goal redirection BPHTB by Act No. 28 of 2009 is none other than to increase local taxing power of Districts and Municipalities that had not run optimally, although the locality object and Building Tax Rural and Urban and BPHTB located in the district and the city. The transfer of voting BPHTB of the Regional Center is not only limited to the collection or billing, but also on data collection, assessment, determination, comprehensive services that should be implemented in addition to the administration of the area.

Forms of local tax revenue one of which comes from Customs Acquisition Rights Over Land And Building (BPHTB). Transactions greatest generate revenues of BPHTB transaction switchover rights and buildings mainly buying and selling of land and buildings, and thus is not an exaggeration to say the role of the Notary as PPAT very significant in achieving acceptance of the target BPHTB and securing BPHTB of transactions switchover rights to land and buildings.

Thus, the local tax is a tax set by local governments with local regulations (Perda), which authorized the collection implemented by local governments and the results used to finance local government spending in implementing governance and development areas. Because local governments in Indonesia is divided into two, namely the Provincial Government and District / City Government, the authority designated by local governments levied each of which is regulated by law.

BPHTB tax requires that the buying and selling prices reported are approaching the fair market value of that property. It is sometimes difficult to implement given the magnitude of the price of the transaction will affect the costs associated with the transaction. Therefore, the seller and the buyer chooses tendency not to include the actual transaction price on the deed of sale made with a view to reducing the cost to be borne by the seller and the buyer. ${ }^{9}$ Therefore, to know the truth of the transaction price listed by the taxpayer, in comparing the price of the transaction in which the taxpayer put the list price of land in each district.

In implementing the local regulations relating to BPHTB levy taxes on land transactions and / or buildings. As for the follow-up of policies made by the Government to explore the potential Demak district in the area are: ${ }^{10}$

\footnotetext{
${ }^{9}$ Marihot P. Siahaan, Ibid, p.165

${ }^{10}$ Results of interviews with Agustin Eka Safitri, Kom, as the Head of Revenue Demak, on May $28,2019,10: 00 \mathrm{am}$
} 
- Readiness of paramount importance is the legality of the voting BPHTB that with the establishment of the Regional Regulation (Perda). Demak regency administration had made a regulation that By Act No. 4 of 2011, which have already been ratified in July 2011 regulation on BPHTB an urgent need to remember on January 1, 2011 the central government is no longer authorized to collect BPHTB. Not the enactment of regulations BPHTB local governments will lose data and information related to the transfer of rights to land and / or buildings, even so still there are some who are concerned about the publication of Regulation No. 4 of 2011 as new validated in July 2011 when voting BPHTB already done from the beginning of January 2011, for their self assessment system where PPAT / Notary and subdistrict depositing own taxes BPHTB her the tax BPHTB received is not taxable illegal because local government can not do polling UN and BPHTB entail the loss of the revenue potential of local revenue (potential loss), which means it will be detrimental to the country.

- The second is the readiness of the Human Resources (HR) The regulation without supported by adequate human resources have the ability to implement the regulation, then it will not help much in improving the regional government through the ballot BPHTB pendapatnnya. HR issues should get attention because during these forces capability areas, especially in the delivery of services in the field of taxation by society is still considered low. As is known, during this time all the data relating to the subject and object BPHTB taxes administered by the Tax Office (KPP) Directorate General of Taxation, Ministry of Finance. BPHTB diversion to the area is not accompanied by a delegation of human resources to the local government tax office. In BPHTB enforcement, removal process will run much more easily because it does not require the skills of human resources and information technology (IT). Basic Training and Tutoring Techniques and regional consultations to continue the monitoring, guidance and assistance from the Directorate General of Taxation.

- Facilities and Infrastructure Readiness The local government tried to set up infrastructure such as what has been prepared by the Directorate General of Taxes such as a computer including information systems, this is because the collection BPHTB can not be separated from the role of IT. Thus, the government will set up facilities and supporting infrastructure as had been prepared by the LTO.

- Organizational Structure and Work Procedure BPHTB devolution to local governments to do the realignment of the organizational structure of work units that perform local tax collection. Local tax collection is handled by the working unit Office / Regional Financial Management Agency in Demak DPPKAD accordance with the groove that has been made.

\subsection{Constraints faced by the Notary and PPAT in Tax levy BPHTB Purchase Transactions Over Land And / Or Building}

At the time of transfer BPHTB, there are a number of obstacles and barriers, especially over BPHTB a new kind of tax for the region. Some of the obstacles that arise according to Budi Ispriyaso ${ }^{11}$ including awareness of each community to implement its obligations in paying the local taxes. Public awareness to implement its obligations in paying taxes is one of the issues that will affect tax revenues. This is in accordance with the said Suyanto ${ }^{12}$ that the factors that affect tax revenues, among others:

\footnotetext{
${ }^{11}$ Budi Ispriyaso, 2005, "Aspek Perpajakan dalam Pengalihan Hak Atas Tanah dan/atau Bangunan karena Adanya Transaksi Jual Beli", in Masalah-masalah Hukum, Volume 34 (4).

12 Suyatno, 1997, Hukum Pajak Surakarta: UNS Pers.
} 
legislation or tax rules, the infrastructure to implement the law or tax regulations, and the awareness of the public.

Based on interviews with Nur Chasanah, SH., MKn, as Notary and PPAT constraints Local Government Policy in Demak In Picking Up BPHTB Tax On the Transaction on the Sale and purchase Land And / Or Building include: ${ }^{13}$

- About the length of BPHTB online submission process, even to the recently completed month verified,

- Determination of the price per meter the market price and the transaction price is determined solely by the clerk DPKKD, as each determines the price per meter is mandatory and must be paid by the applicant, so the applicant could not refuse.

- The submission process is too complicated requirements.

\section{Closing}

- Conclusion

- Policies implemented by the Central Government is to give broad authority to manage their own household, including the authority to explore potential financial income areas one of which is the local tax. BPHTB tax requires that the buying and selling prices reported are approaching the fair market value of that property. It is sometimes difficult to implement given the magnitude of the price of the transaction will affect the costs associated with the transaction

- Some of the obstacles faced by the Notary and PPAT The BPHTB levying taxes as dishonest taxpayers to include the value of the transaction, the clerk is still difficult and takes a long time in the field verification process, lack of transparency in the market price of land, lack of good ithikad the seller, as well as the lack of public knowledge about this BPHTB tax

- Suggestion

- Local Government should pay attention to several aspects in issuing regulations or policies of the Tax on Acquisition of Land and Building, these aspects include the conditions of their taxes and conditions masyarakatagar rules or policies are useful and not burdensome to society,

- The policy of collecting duties on Acquisition of Land and Buildings must cooperate with the Notary / PPAT as well as the local Land Office.

\section{BIBLIOGRAPHY}

[1] Budi Ispriyaso, 2005, "Aspek Perpajakan dalam Pengalihan Hak Atas Tanah dan/atau Bangunan karena Adanya Transaksi Jual Beli", in Masalah-masalah Hukum, Volume 34 (4).

[2] J.Supranto, 2003, Metode Penelitian Hukum Dan Statistic, PT.Rineka Cipta, Jakarta,

[3] Ministry of Finance of the Republic of Indonesia, the Review of Implementation of Transfer of Tax on Acquisition of Land and Building (BPHTB) into Local Tax, (Jakarta: Directorate General of Fiscal Balance, 2011)

[4] The preamble of Act Number 21 of 1997 on Customs Acquisition of Land and Buildings.

${ }^{13}$ Results of interviews with Nur Chasanah, SH., MKn, as notary and PPAT in Demak, on May 26,2019 , at $10.45 \mathrm{pm}$. 
[5] Rochmat Soemitro in Mardiasmo, 2011, Perpajakan, Revision Edition, Penerbit Andi Offset, Yogyakarta

[6] Setu Setyawan and Eny Suprapti, 2006, Perpajakan, Bayumedia Publishing dan UUM Press, Malang

[7] Suyatno, 1997, Hukum Pajak, Surakarta: UNS Pers.

[8] Results of interviews with Nur Chasanah, SH., MKn, as notary and PPAT in Demak, on May 26, 2019, at 10.45 pm.

[9] Results of interviews with Agustin Eka Safitri, Kom, as the Head of Revenue Demak, on May 28, 2019, 10:00 am 